and Almelo will be owned and run by subsidiary companies of an enrichment organization which will provide 51 per cent of the equity capital of each subsidiary and with headquarters in Britain. Thus the capital for the Almelo plant, for example, will be 51 per cent from the enrichment organization and 49 per cent from West Germany and Holland. The entire arrangements will be supervised by a joint committee from the three countries which will deal with questions to do with the non-proliferation treaty, security, and arrangements with other countries.

There has been no exchange of technical information yet, but it is believed that Britain is going to learn a lot from cooperation with the Dutch. Even so, it looks as though the agreement is meant to be taken as a model of the kind of cooperation in advanced technology which the Ministry of Technology would want to become commonplace if Britain joined the European Economic Community. Mr Benn stressed that the agreement would be different from other European ventures--people hope it will be more successful than some--because it will involve essentially industrial collaboration with a minimum of government supervision through the joint committee. The shares of both the enrichment organization and the organization. which builds the plants will be held by commercial enterprises nominated by the three governments. The hope is, of course, that the arrangements will be integrated into the EEC. Collaboration with other countries beyond the three so far extends to informal discussions with Italy and Belgium, and Sweden has expressed interest.

\section{FOOT AND MOUTH}

\section{Viruses in the Wind}

Three paragraphs on airborne virus transmission are by all accounts the most scientifically significant contents of Part Two of the Northumberland Committee's report on foot and mouth disease, published on December 16 (HMSO, $12 s 6 d$ ). The importance lies not so much in what the report says - about the persistence of the virus in humid air and its transport by wind for over sixty miles in ideal conditions-as in the implications of the research on which it is based. Some veterinary scientists now believe that at least 90 per cent of the spread of the disease is caused by the wind, and that the value of some of the control measures to isolate farms and restrict movements within infected areas is chiefly psychological.

The report complements the prophylactic recommendations of Part One, which was published in June, by examining what should be done after the disease has broken out. Nearly all of its conclusions have already been accepted by the Minister of Agriculture: they deal with the organization of control centres, the restrictions of movement and access required to contain the diseasc, and compensation for farmers whose herds have been depleted. In effect, they tighten up existing regulations in the light of the 1967-68 epidemic, and reject some of the emergency action. taken at the time. Disinfected pads on roads, for example, seem to have been useless in that they did not affect any likely route of transmission.

If airborne infection is the main source of foot and mouth disease, the Northumberland Committec's recommendations are by no means irrelevant. The disease is so obviously contagious that everything possible must be done to keep susceptible animals apart. On the other hand, it may be that the recommendations are silent on the role of wind and rain in spreading the disease because much of the basic evidence has only come to light in the last few months, largely as a result of work by P. B. Wright (Weather, 24, 204; 1969) and L. P. Smith and M. E. Hugh-Jones (Nature, 223, 712; 1969).

Smith and Hugh-Jones showed that in four British epidemics the pattern of spreading was almost entirely downwind, and suggested that rainfall was important in depositing virus particles. There is some controversy over how the disease was actually picked up, because although animals could have grazed in damp grass on which the virus had been deposited it has been claimed that the virus is much more infectious when it is inhaled in the form of an aerosol. What seems to be agreed, however, is that virus will travel in the wind when the weather is humid. There is no evidence that virus particles actually are deposited on to foodstuffs in rain rather than inhaled from the atmosphere, but there are plenty of correlations between the way the disease has spread and the direction of the wind, and it is significant that outbreaks always seem to begin in wet weather.

Buried in the report's suggestions is the idea that an epidemiological team should be based on each control centre. Whether such a team would be expected to make full use of the knowledge about airborne transmission is not clear, but at the moment an epidemiology unit of the Ministry of Agriculture, said to be existing on paper rather than in practice, does include meteorologists. The report itself mentions that meteorologists who this year studied an outbreak that occurred in 1960 were able to predict from weather data alone exactly how the disease spread. If such forecasts could be made rapidly in the event of a fresh outbreak, they would presumably be useful in determining areas to be placed under restriction; but on this possibility the report makes no explicit recommendations, saying in a postscript simply that "this approach will be valuable ... in indicating where to look for secondary outbreaks".

By keeping the wind evidence separate from its suggestions for governmental action, the report thus gives the appearance of concentrating its attention chiefly on stopping paths of transmission that may be relatively unimportant. The committee kept to the view expressed in Part One of its report that voluntary vaccination of animals should not be permitted. If, however, virus can travel sixty or so miles in the air, unvaccinated animals could be susceptible to infection that is imported by an otherwise uncontrollable route, and Wright has pointed to the possibility of airborne transmission from the Continent in several recent outbreaks.

\section{BOTANY \\ Cancerous Peas}

\section{from our Botany Correspondent}

THE study of neoplastic pea pods has become one of the chief concerns of the applied genetics department of the John Innes Institute according to the latest 
annual report $(1968,30 \mathrm{np})$, the second to come from the institute's new home in Norwich. The development of neoplastic growths on the pods of peas, as shown in the picture, is due to a single dominant gene, the activity of which is affected by the quality of light falling on the pod.

The latest development for the investigation of this phenomenon has been a special agar culture medium, containing yeast extract and a high concentration of salts, in which the growths form more quickly than they do in vivo. Experiments are in progress to determine the effects of specific bands of light when applied to different parts of the pod. The intention is to treat pods with tritiated thymidine, dissect away the epidermis, using a new technique, and locate autoradiographically the site of incorporation of the isotope, which will be the site of initiation of the neoplasm.

The other chief concern with peas is the problem of rogues, inferior plants which deviate from the usual characteristics of a variety of breed, and which are produced by the activity of unstable genes. Members of the department have been investigating this phenomenon for several years, and now with a new chief, Professor D. R. Davies, the work has been reinvigorated and expanded to cover other aspects of the biology of the garden pea. Biometrical and pathological investigations have begun, to support a full plant breeding programme. Oddly enough, there has been no government support for research into the breeding of the pea, in spite of the need to step up production to counteract the present rate of importation of 60,000 tons per year, worth about $£ 3,000,000$.

Since Professor R. Markham became director of the institute it has absorbed the ARC Virus Research Unit which he headed at Cambridge, and virological activities at Norwich are now considerable. During 1968 the first evidence clearly emerged for a virus infection of a fern. Rod shaped particles were successfully transferred between individuals of hartstongue fern, Phyllitis scolopendrium, and the male fern, Dryopteris filix-mas. Similar particles have also been found in some other ferns, and the virus seems to be transmitted through the soil, possibly by nematodes. It will no doubt be interesting to see whether viruses have anything to do with the degeneration of bracken on Ilkley Moor, which is to be the subject of a special study.

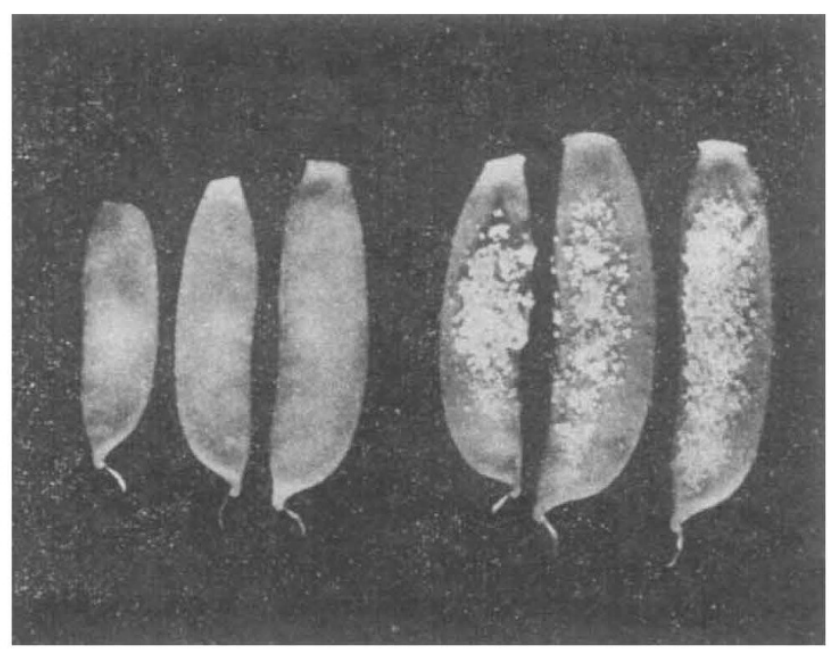

Neoplastic pea pods on the right, and normal pods on the left.

\section{Miscellaneous Intelligence}

The Ministry of Agriculture has just published the proceedings of a symposium on soil science that was held on October 22-23, 1964, with the comment that "the papers brought together the most recent information on the subject". It is odd that a ministry which banned cyclamates at seven days' notice should take five years to publish a 178 page book, but perhaps this is a case of the tail not knowing where the head is buried.

Ix the three weeks between November 11 and December 4, Dr Glenn T. Seaborg, chairman of the US Atomic Energy Commission, delivered nine speeches totalling some 70,000 words. Is this a record?

News that a Georgian scientist, Dr Galina Kandelaki, has successfully pollinated wheat with pollen from a cactus need not be viewed with too much alarm. This is no exercise to set the desert blooming with prickly wheat but only an instance of the phenomenon known as pseudogamy, in which a foreign pollen can sometimes set a seed into parthenogenetic development. Dr Kandelaki hopes the cactus pollen will goad into fertility hybrid wheats that have so far proved sterile.

\section{Years Ago}

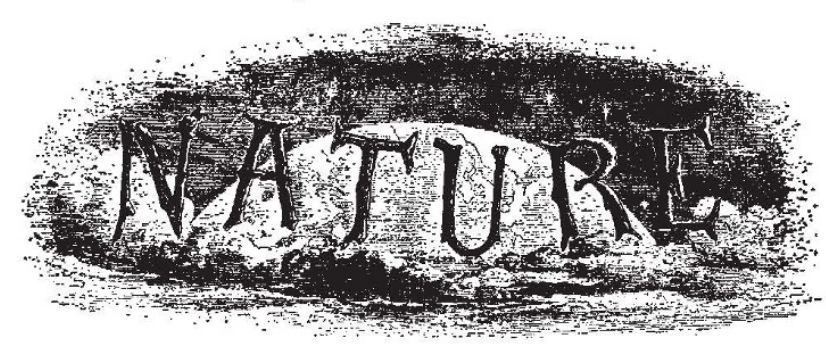

\section{A DEDUCTION FROM DARWIN'S THEORY}

THERE is one important consequence deducible from Darwin's profound theory which has not yet been noticed so far as I am aware. The theory is capable under certain reasonable conditions of accounting for the fact that the highest forms of civilisation have appeared in temperate climates.

I conceive it to be the essential consequence of Darwin's views that no form of life is to be regarded as a fixed form; but that all living beings, including man, are in a continual process of adjustment to the conditions in which they live. If this be so, it will of necessity follow that the longer any race dwells in given circumstances, the morc perfectly will it become adapted to those circumstances. A migratory race, on the contrary, will always be liable to enter climates unsuited to it, and less favourable to the development of the greatest amount of energy. Negroes can bear a tropical heat simply because the race has grown more accustomed to it than Europeans, who bring with them indeed a superior degree of energy and intellect, but soon sicken and fail to reproduce themselves in equal perfection.

From a leading article by $W$. Stanley Jevons in Nature, 1, 231, December 30, 1869. Jevons was the English economist who suggested that commercial crises and the sunspot cycle might be interrelated. 